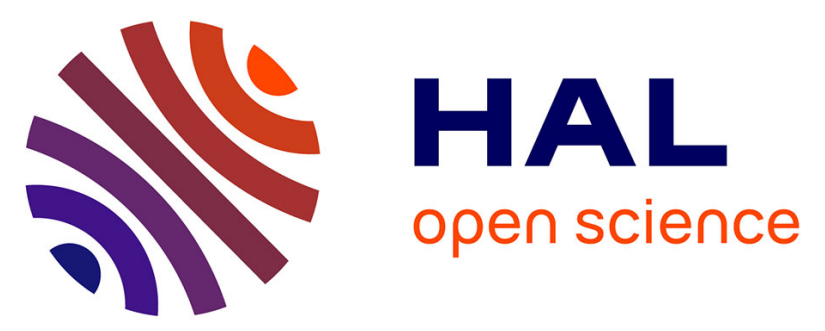

\title{
Addendum to \&apos;Is long-term autogenous shrinkage a creep phenomenon induced by capillary effects due to self-desiccation?\&apos;
}

\author{
Abudushalamu Aili, Matthieu Vandamme, Jean Michel Torrenti, Benoit \\ Masson
}

\section{To cite this version:}

Abudushalamu Aili, Matthieu Vandamme, Jean Michel Torrenti, Benoit Masson. Addendum to \&apos;Is long-term autogenous shrinkage a creep phenomenon induced by capillary effects due to self-desiccation?\&apos;. Cement and Concrete Research, 2019, 115, p. 568. 10.1016/j.cemconres.2018.07.001 . hal-02305980

\section{HAL Id: hal-02305980 \\ https://hal.science/hal-02305980}

Submitted on 29 Jun 2020

HAL is a multi-disciplinary open access archive for the deposit and dissemination of scientific research documents, whether they are published or not. The documents may come from teaching and research institutions in France or abroad, or from public or private research centers.
L'archive ouverte pluridisciplinaire HAL, est destinée au dépôt et à la diffusion de documents scientifiques de niveau recherche, publiés ou non, émanant des établissements d'enseignement et de recherche français ou étrangers, des laboratoires publics ou privés. 


\section{Addendum to "Is long-term autogenous shrinkage a creep phenomenon induced by capillary effects due to self-desiccation?"}

by Abudushalamu Ailia, Matthieu Vandamme ${ }^{a}$, Jean-Michel Torrenti ${ }^{b}$, Benoit Masson ${ }^{c}$

a Université Paris-Est, Laboratoire Navier (UMR 8205), CNRS, École des Ponts ParisTech, IFSTTAR, Marne-la-Vallée F-77455, France

${ }^{b}$ Université Paris-Est, IFSTTAR, 14 Boulevard Newton, Champs-sur-Marne F-77420, France

c EDF-DIN-SEPTEN, Division GS - Groupe Génie Civil, 12-14 Avenue Dutriévoz, Villeurbanne F-69628, France

Prof. F.-J. Ulm brought to our attention that we forgot to include an important reference in our manuscript. Indeed, Ulm et al. (1999) showed that, for 5 concretes that differed in their water-tocement ratio and for which basic creep and autogenous shrinkage were measured by Le Roy (1996), the long-term kinetics of autogenous shrinkage could be explained by creep of the solid skeleton under the action of an internal pore pressure. Their conclusion was based on the observed linearity of the relationship between basic creep compliance and increase in autogenous shrinkage in the long term.

From the slope of this linear relationship, they back-calculated an "effective pore pressure" displayed in Figure 1. Interestingly, this uniaxial "effective pore pressure" -merely calculated from macroscopic observables- is in very good agreement (both in terms of magnitude and in terms of trend with water-to-cement ratio) with the capillary stresses that we estimated at the pore scale with the help of micromechanics (see Fig. 6 in our manuscript). The reason for this agreement lies in Eq. 16 of our manuscript, which reads $\Sigma^{\infty}=\sigma^{\infty}$ and shows that, in the linear viscoelastic case with a viscoelastic Poisson's ratio of the matrix equal to 0.2 , the long-term "effective" macroscopic stress $\Sigma^{\infty}$ that acts at the scale of the concrete sample is equal to the long-term microscopic stress $\sigma^{\infty}$ that acts on the $\mathrm{C}-\mathrm{S}-\mathrm{H}$ gel.

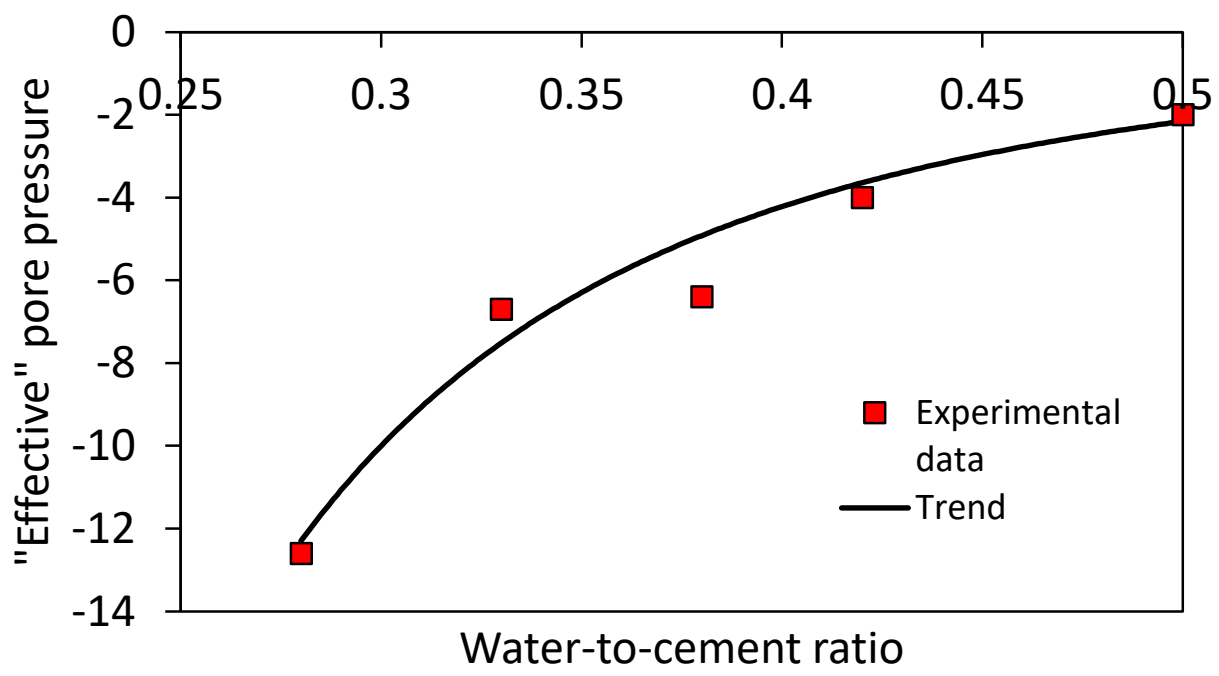

Figure 1: Uniaxial "Effective pore pressure" versus water-to-cement ratio, as reported by Ulm et al. (1999). Figure adapted from Ulm et al. (1999). 


\section{References}

Ulm, F.-J., Le Maou, F., \& Boulay, C. (1999). Creep and shrinkage coupling: new review of some evidence. Revue Française de Génie Civil, 3, 21-37.

Le Roy, R. (1996). Déformations instantanées et différées des bétons à hautes performances. Etudes et recherches des laboratoires des ponts et chaussées, OA22, Laboratoire Central des Ponts et Chaussées, Paris, 1996. 